\title{
The Development of Chamber Music in Baroque Period and Its Style Deduction
}

\author{
Chenyu Wang \\ Gannan Normal University \\ Ganzhou, China 341000
}

\begin{abstract}
As a very important period in the history of European music, Baroque music is famous for its unusual writing and performing methods. This author, taking the chamber music of Baroque period as the research direction, tries to explain the performing methods and processing techniques of the chamber music in the Baroque period by many years of experience in Europe.
\end{abstract}

\section{Keywords-Baroque; chamber music; style deduction}

\section{INTRODUCTION}

In the history of music, it is usually called the Baroque period from 1600 to 1750 . The musical style of the Baroque period has changed dramatically. The birth of the opera and the development of the instrumental music symbolized the establishment of the new style of Baroque. Vocal music and instrumental music, as the two branches of music, began to complement and interact with each other, and develop independently. The church style was gradually replaced by the major and minor style. The use of the figured bass gave rise to the new concept of harmonics. Polyphony is gradually transferred to the style of homophony. Grace notes are widely used on musical score and non-score. Emotional resonation expresses the musicians' praise for religious gods and justice. Chamber music, as a very important type in Baroque period, appeared on various stages. Unlike the solo, the chamber music performance in the Baroque period was famous for its unique style. Based on my research experience in Europe for many years, I hope to provide some practical suggestions for readers in performance and teaching.

\section{THE DEVELOPMENT OF CHAMBER MUSIC IN THE BAROQUE PERIOD}

The term of "Baroque" comes from Portuguese "Baroco", and some scholars think it comes from Italian. It is called as "irregular pearls". Originally used in architecture in Italy in the 17 th Century, this style gives art a sense of fanaticism and riots.

Chamber music originally referred to music played by a few people in the room of the Western aristocratic court and performed for a few listeners. Now it refers to the small instrumental music played by more than two instruments, which is different from the large orchestral music.

The earliest chamber music was born at the end of the Sixteenth Century, and the chamber music really started and began to develop in the Baroque period (1600-1750). The early
Sonata is often confused with the name of cansona, almost the same in structure. They are all instrumental music with multiple paragraphs ${ }^{1}$. The sonata is usually written for 1 or 2 violins and ensemble bass, while cansona is usually written for instrumental ensembles or keyboard instruments. Until the middle of Seventeenth Century, cansona was replaced by sonata. The new style of sonata becomes larger in scale and less in number.

Throughout the Baroque period, the development of chamber music has reached an unprecedented level. The important types of chamber music in Baroque period were the trio sonata ${ }^{2}$ and solo sonata ${ }^{3}$. These two types of chamber music usually use violin or trumpet as solo instrument, and thorough bass is harpsichord or bass string instrument.

In the late Baroque period, the form of sonata was improved obviously, and the popular sonata type evolved into sonata da camera and sonata da chiesa. Two different styles of sonata complemented each other in the changing years. In a long period of development, it got rid of the stale and took in the fresh. There appeared a dance movement in the serious sonata da chiesa, and serious polyphonic passages ${ }^{4}$ were introduced into the simple sonata da camera.

Sonata da camera, which originated in the late Sixteenth Century, refers to dance music made up of a series of forms, such as Courante, Allemande, Sarabande and gigue. Sonata da camera is an important type of music to entertain aristocrats in royal court or performed in private concerts.

Sonata da chiesa refers to the sonata played in the church. Its musical style is more serious and solemn. Sonata da chiesa usually appears in the form of "prelude" in ceremonies or before mass. It can also take place of a mass or a paragraph of a day-class ceremony. The typical mass music of the church includes four contrastive movements of slow-fast-slow-fast pattern. The first movement is usually $4 / 4$, and the whole style is very serious and solemn. The second movement is 4/4 (2/4). The texture is often the imitation contraposition of the Fugue.

Shen Xuan, Gu Wenxian and Tao Xin. Introduction to Western Music History. Shanghai: Shanghai Music Publishing House, 2004 (10): 128.

Trio Sonata: Two violins and two thorough bass instruments (here referring to Trio Sonata in Baroque period).

Solo Sonata: Solo instrument and two thorough bass instruments (here referring to Solo Sonata in Baroque period).

Shen Xuan, Gu Wenxian and Tao Xin. Introduction to Western Music History. Shanghai: Shanghai Music Publishing House, 2004 (10): 129. 
The third movement is lyric $2 / 2$, with beat characteristic of Galliard and Sarabande. The fourth movement has the beat characteristics of the fast dance music, such as minuet and gigue. The overall is of a harmony texture.

\section{The CharaCteristics OF CHAMBER MUSIC IN THE BAROQUE PERIOD}

The main characteristics of Baroque music are the use of figured bass, contrast effect and grace notes. In the Baroque period, the form and structure of music constantly developed and evolved, thus presenting a complexion of new and old coexistence and transformation. The main characteristics of chamber music can be expressed as follows:

\section{A. Figured Bass}

It emphasizes the melody lines at the two ends of the voice part. It has an independent bass voice that continues throughout the work, so it is also called as thorough bass. The thorough bass of chamber music was usually performed through organ, harpsichord, lute or other basses in Baroque period. The use of "figured bass" has solved the complicated form of writing. Musicians can calculate the actual harmony in voice part through numeral marked on the score, and improvise it.

\section{B. The Transfer of Polyphony Style to Homophony Style}

In the Baroque period, the development of music is moving forward in several directions at the same time, and the form and structure of music are constantly evolving. The style of polyphony has developed more mature during the Renaissance, and the stable polyphonic music of the Renaissance cannot meet the needs of the people in the new period. The artists in Baroque period were influenced by the new humanistic and artistic thoughts, and they wanted to pursue a brand new form of creation. The style of polyphony has obviously no longer conformed to the popular aesthetic view of the time. Under the hard work of many parties, the style of homophony was created, and it became the leading role in the music.

\section{The Appearance of Major and Minor}

In the Baroque period, Corelli was one of the first musicians to play major and minor thoroughly. He composed works completely in accordance with the major and minor, and in fact, he achieved a free tune. Modulations in the movement are clear in logic, usually transferred to a subdominant, and minor to a relevant major. This principle of modulation was used by Vivaldi, Handel, Bach and others.

\section{Rhythms in Beat}

In the Baroque period, in order to create a new style of art, people boldly added the elements of dance music into the rhythm of music. Most of the rhythms and beats in this period were derived from dance music. Its rhythm is mostly in two contrasting forms, solemn and lively. The main types of dance music used are: minuet, folias, gavotte, bourree and so on. These are reflected in the chamber music of Bach, Corelli and Vivaldi, such as Bach's "Violin Concerto in D minor", Corelli's
"Violin Sonata in D minor", Handel's instrumental solo sonata, and so on.

\section{E. The Use of Grace Notes}

The term of "Baroque" originally meant the irregular shape of pearls. Artists intended to break the old-fashioned and humorless artistic image of the Renaissance, so as to create distinctive, gorgeous and distinct musical features. Under the influence of the new trend of thought, artists tried different ways to build their own "non-straight" music style. In order to change the straight music in the Renaissance, musicians added a large number of grace notes to enrich their melodies. These grace notes frequently appear in chamber music during the Baroque period in the form of score or non-score (improvisatori).

\section{F. The Gradually Perfect Artistic Contrast Technique}

Looking back from the history of Baroque period, "exaggeration" and "magnificence" are people's undeniable comments on this period. In order to achieve the "magnificent" musical effect, artists used contrast technique as creation means in addition to using a large number of grace notes in the Baroque period. The strong contrastive technique is reflected in many aspects, such as the contrast of tempo, the contrast of the intensity and the contrast of the dynamics, the contrast of pitch, the contrast of instrumental tone.

\section{G. Emotional Resonance}

The Baroque period is an era full of idealism and strong religious flavor. In this period, most of the works were in imitation of human emotions, with religion as creation background, and then added some folk myths. It was mainly to express a broad sense of humanitarianism, praise the true, the good and the beautiful, and criticize the ugly in the world. It expresses the praise and admiration of musicians for religious gods and justice.

\section{The PERformance Methods of CHAMber Music IN THE BAROQUE PERIOD}

Chamber music was established in the Baroque period, and many composers, such as Bach, Vivaldi and Corelli, had many chamber music compositions. In this gorgeous, slightly exaggerated, religious era, from the perspective of performance techniques and music processing, there are many problems that deserve our in-depth study.

\section{A. The Time Value of Long Tones}

As an example of Bach's work, whether it is the unaccompanied sonata of the cello or the Concerto with two violins, the composer marked the time value on the score very clearly. However, does it mean that we should perform as same as the score marked? First, the performer needs to ensure the beat and rhythm in the repertoire. Secondly, consider the music style, taking Bach's Concerto with two violins in D minor as an example. The rhythms of the string music and thorough bass part are very neat, and many long sounds have appeared in the three movements. Long tones cannot be filled with time values, because the Baroque chamber music is 
usually played in the open room of a church or court, often accompanied by echo effect. If the time values of the long tone are full, it will cause differences in hearing. Music can create duration before transmitting into the ears of audience through such an open space. Therefore, in the performance of chamber music of Baroque period, the value of the long tone cannot be full or longer, in "Fig. 1".



Fig. 1. Bach's Concerto with two violins in D minor.

\section{B. The Bowing of String Music}

Like the Baroque architecture, most of the music at that time also presented an arc shape. We have learned through a lot of pictures and videos that string instrument makers of
Baroque period made the bow of the string instrument relatively short, bar curved and hair with a small arc in order to facilitate the bowing action in performance, as shown in the following figure, in "Fig. 2":

Fig. 2. Fiddlestick.

Times are changing. With the advance of history, the fiddlestick in Baroque period is very few in today's stage. Nowadays, the fiddlestick of string instrument has evolved into modern fiddlestick which is straight in parallel with arch bar and hair and has increased in length, as shown in the following figure, in "Fig. 3":

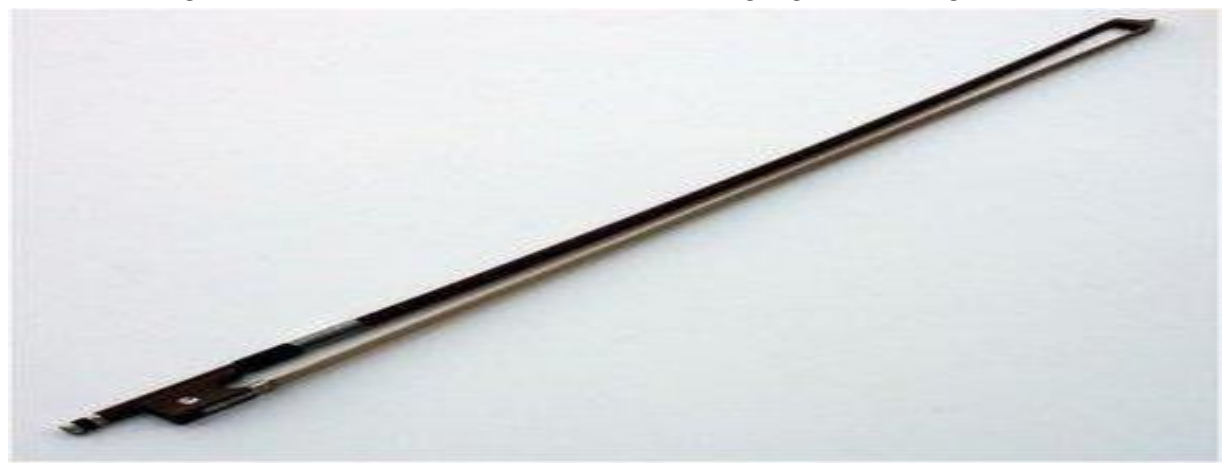

Fig. 3. Fiddlestick.

Therefore, when we play the string chamber music of Baroque period, we should create a feeling of air between bow and string, and perform bow with a radian and to be rounded. In particular, it is important to note that the bowing of other periods cannot be used in the Baroque period, and the bow cannot be pressed completely. The bowing speed and intensity should be adjusted according to the specific music.

\section{The Use of Modern Piano Pedal}

We all know that there is no pedal in the Baroque clavichord. In order to keep the continuity and melody of the voice parts, the composer usually added a large number of tenuto and grace notes. Therefore, when we play the music of Baroque period with modern piano, we shall not use the pedal too much. We should follow the performing rules of Baroque period. We can step down the pedal a little when dealing with music notes with connection line.

\section{The Balance of Voice Parts}

As the most prominent feature, polyphony plays a pivotal role in the Baroque period. Composers give each voice part the same "status" and each voice part flows and supplements each other. If a certain part of the music in this period is played too expressive or prominent, it will result in the destruction of the whole structure. 


\section{E. The Fingering of String Music Part}

Whether performing solo and chamber music in Baroque period, we should pay attention to the intelligent use of fingering. The proper use of fingering directly affects the timbre of musical instruments. Take Corelli's works as an example. In a violin sonata fragment, the first section repeats two "a" tones. Think it with present performing way, and we will not hesitate to play "a" with d string and fourth figure. But Corelli's music was the model of the Baroque period. In the Baroque period, performers tended to use open string to perform pitch of string instruments. Open string of string instrument could give a sense of space in chamber music performance. On contrary, if we replace open string with other figuring, it will be rigid and lack of echo effect, and then it is difficult to show the baroque style in "Fig. 4"

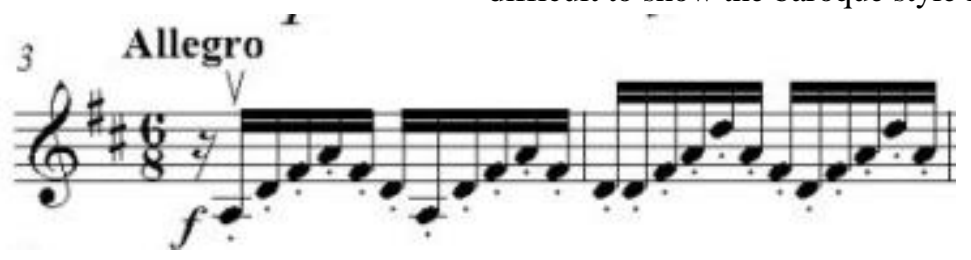

Fig. 4. Corelli's first violin sonata.

\section{F. Changes in the Intensity of Music}

The intensity of music in the Baroque period was processed differently, which is mainly shown in the following two aspects:

First, when the upper and lower scales appear in the work, the actual effect should be performed as crescendo in ascending and decrescendo in descending gradually.
Second, when notes with different values appear in the same sentence and phrase, the note with shorter value should be played as forte, and the note with longer value should be played weaker. The specific intensity should be changed according to the actual music in "Fig. 5".

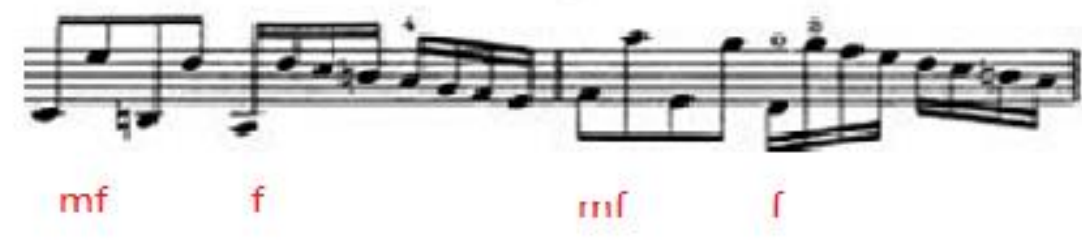

Fig. 5. Bach's chamber music.

\section{CONCLUSION}

Generally speaking, the development of chamber music in Baroque period has reached unprecedented level. Many new types of chamber music have come into being and developed. Today, when we look back at this history and music, we cannot help but sigh for the precious wealth that this great era has given us. We are constantly exploring and carrying out textual research by looking up the data left by the ancestors, and its deductive style is still a hot topic. How to perform music originally according to the score is still a question worth pondering.

\section{REFERENCES}

[1] Shen Xuan et al. Introduction to Western Music History. Shanghai: Shanghai Music Publishing House, 1999. 沈旋等编.西方音乐史简编 [M].上海: 上海音乐出版社, 1999.

[2] Wang Xuqing. Music Poetics: the Heyday of Musical Rhetoric in Baroque Period. Beijing: Music Research, 2017. 王旭青.音乐诗学: 巴 洛克时期音乐修辞的全盛期 [J].北京：音乐研究， 2017 .

[3] Wang Guangxi. Analysis of the Characteristics of Music in Baroque Period. Xi'an: Symphony - Journal of Xi'an Conservatory of Music,
2016. 王光䂀. 探析巴洛克时期的音乐特征[J].西安：交响-西安音乐 学院学报,2016.

[4] Yu Yunyang. General History of Western Music. Shanghai: Shanghai Music Publishing House, 2003. 于润洋.西方音乐通史 $[M]$.上海: 上海 音乐出版社,2003.

[5] Liu Yanli, Shen Yonghua et al. Western Music. Beijing: People's Music Publishing House, 1996. 刘延立、沈永华等人编译.西方音乐漫话 $[\mathrm{M}]$ 北京：人民音乐出版社，1996. 